\title{
Editors' Report 2016
}

\section{Changes in Editors}

Paul Jensen is relinquishing his position as Co-editor of The Australian Economic Review and Editor of the Data Survey section. He will be replaced in 2017 as Co-editor by Chris Ryan. Responsibility for the data surveys will be handed to John Haisken-DeNew. Efrem Castelnuovo will become the Policy Forum Editor.

\section{Articles and Submissions}

The Review's established format of invited articles, contributed articles, a policy forum, a data survey and a section 'For the Student' were continued in 2016. Readership continues to grow, especially in Asia. Annual full-text downloads are around 75,000, with 42 per cent from overseas. The Thomson Reuter Impact factor has risen to 0.552 . The review of the Australian economy, published annually in the March issue, continues to engender high downloads. The Policy Forum articles also enjoy high readership. They covered: the macroeconomic consequences of macroprudential policies; research and innovation; housing policy; and the economics of ageing.

A summary of the composition of the articles published in the Review over the past 3 years is given in Table 1. Table 2 provides information on the number of articles received and their disposition. Submissions to the Contributed Articles section increased by 10 per cent to 58 in 2016. The increase was not matched by acceptance rates, as more submissions were received from overseas authors and these were often too narrow in focus for the Review. While we welcome submissions from international authors, it is our intention that the Review remain a policy-oriented journal with particular relevance to Australia and the Asia-Pacific region.

For submissions over the 3 year period 2014-2016, the acceptance rate on papers for which a decision has been reached was 22 per cent. Submissions which are outside the aims of the Journal or clearly do not meet the required standard are rejected by the editors without going to referees: this applied to 31 per cent of submissions over the 3 years 2014-2016. As befits a policy-oriented journal, we aim to keep the time between acceptance of articles and final publication in an issue of the Journal to around 6 months. The current backlog of accepted articles awaiting publication represents two issues.

This is the author manuscript accepted for publication and has undergone full peer review but has not been through the copyediting, typesetting, pagination and proofreading process, which may lead to differences between this version and the Version of Record. Please cite this article as doi: $10.1111 / 1467-8462.12218$ 


\section{Referees}

At least two referees are used for submissions of contributed papers that proceed to the refereeing process. We also use referees for the other sections of the Journal. The integrity of the system of peer review is crucially dependent on the work of our referees. Editors of Australian journals continue to press for greater recognition of refereeing and editorial work by universities and the Australian Research Council in its Excellence in Research for Australia exercise. In another, unrelated initiative, the international website $<$ www.publons.com> has been established in order to give recognition to the work of referees.

We thank our referees warmly for their contributions in providing a large number of constructive comments, both to the authors and the editors. The referees in 2016 were Darryl Biggar, Boyd Blackwell, Jeff Borland, Markus Brueckner, Adam Butt, Lixin Cai, Lisa Cameron, David Carroll, Terence Cheng, Mark Crosby, Fabrice Etile, Jim Forrest, Gigi Foster, Khusrav Gaibulloev, Pablo Guillen, Hyeon-Sueng Huh, Joachim Inkmann, Nikhil Jha, Michael Keen, Shahrukh Khan, Parvinder Kler, Ian McDonald, Donald MacLaren, Bill Malcolm, Tim Moore, Di Nicol, Richard Pomfret, Peter Siminski, Kevin Staub, Christoph Stork, Chris Tombazos, Sam Tsiaplias, Joaquini Vespignani, Tania Voon, Roger Wilkins, Jenny Williams, Glenn Withers, Mark Wooden, Jongsay Yong, Peter Yule and Shiji Zhao.

\section{Further Acknowledgements}

We are greatly indebted to Nellie Lentini for her invaluable contributions as the Assistant Editor. Abbey Treloar has provided excellent administrative assistance during the year. Thanks also to Michael Coelli for his work in soliciting and editing papers for the section 'For the Student'. Finally, we wish to thank the team at our publisher, Wiley.

Ross Williams (Managing Editor)

Paul Jensen (Co-editor)

Ian McDonald (Co-editor)

January 2017

Table 1 Published Articles, 2014-2016

\begin{tabular}{lccc}
\hline Type of article & 2014 & 2015 & 2016 \\
\hline Invited Article & 2 & 2 & 3 \\
Contributed Article & 14 & 15 & 14 \\
Policy Forum & 21 & 21 & 18 \\
Data Survey & 4 & 4 & 4 \\
For the Student & 4 & 4 & 4 \\
$\quad$ & & & \\
Number of pages & 580 & 452 & 524 \\
\hline
\end{tabular}

Table 2 Outcomes of Submissions of Contributed Articles, 2014-2016 


\begin{tabular}{lccc}
\hline Contributed papers & 2014 & 2015 & 2016 \\
\hline $\begin{array}{l}\text { Brought forward from } \\
\text { the previous year }\end{array}$ & 25 & 23 & 16 \\
$\begin{array}{l}\text { New submissions during } \\
\text { the year }\end{array}$ & 53 & 52 & 58 \\
Total & 78 & 75 & 74 \\
& & & \\
Decisions made & & & \\
$\quad$ Published & 14 & 14 & 14 \\
$\quad$ Accepted: awaiting & 6 & 7 & 7 \\
$\quad$ publication & 41 & 45 & 43 \\
$\quad$ Rejected/withdrawn & 9 & 6 & 6 \\
$\quad$ Awaiting revision & 8 & 3 & 4 \\
In process & 78 & 75 & 74 \\
Total & & & \\
\hline
\end{tabular}




\section{University Library}

\section{- M M I E E R VA A gateway to Melbourne's research publications}

Minerva Access is the Institutional Repository of The University of Melbourne

Author/s:

Williams, R;Jensen, P;McDonald, I

Title:

Editors' Report 2016

Date:

2017-06-01

Citation:

Williams, R., Jensen, P. \& McDonald, I. (2017). Editors' Report 2016. AUSTRALIAN

ECONOMIC REVIEW, 50 (2), pp.251-252. https://doi.org/10.1111/1467-8462.12218.

Persistent Link:

http://hdl.handle.net/11343/292961 